\title{
Evaluation of Anti-Cancer Effects of Lycopene extracted from Pink Guava Psidium guajava $L$. and its Combination with Apigenin or Resveratrol
}

FABIENNE PRIAM ( $\square$ fabienne.priam@univ-antilles.fr)

University of Antilles - University Campus Schoelcher: Universite des Antilles - Campus de Schoelcher https://orcid.org/0000-0001-5096-5685

Odile Marcelin

Université des Antilles: Universite des Antilles

Roselyne Marcus

Université des Antilles: Universite des Antilles

Anne Wijkhuisen

CEA Paris-Saclay Center - Fontenay-aux-Roses Site: Commissariat a l'energie atomique et aux energies alternatives Site de Fontenay-aux-Roses

Emilie Juliette Smith-Ravin

Université des Antilles: Universite des Antilles

Primary research

Keywords: Lycopene, Apigenin, Resveratrol, Prostate cancer, Melanoma, Psidium guajava L.

Posted Date: July 1st, 2021

DOl: https://doi.org/10.21203/rs.3.rs-626677/v1

License: (c) (1) This work is licensed under a Creative Commons Attribution 4.0 International License. Read Full License 


\section{Abstract \\ Background}

Active biomolecules extracted from plant biodiversity appear to offer an alternative to the frequently toxic chemotherapy methods used to treat cancer. The micronutrients obtained from certain fruits, including pink guava Psidium guajava L., appear to have this property. We therefore focused on three biomolecules of interest: lycopene and apigenin, the main components in pink guava, and resveratrol, a reference biomolecule with recognized beneficial effects. Our aim was to assess and compare the activities of these micronutrients, first separately and then in combination, on LNCaP cells (prostate cancer) and UACC cells (melanoma).

\section{Methods}

MTT assays and confocal microscopy using anti-PCNA and anti-5-a-reductase antibodies enabled us to establish a ranking for these micronutrients for the first time, when they were studied separately to begin with, in terms of their anti-proliferative action.

\section{Results}

Apigenin was found to be the most active biomolecule in this respect, followed by lycopene and then resveratrol. In a subsequent study of the combined actions of these molecules, specifically "lycopeneapigenin" and "lycopene-resveratrol", we found that the "lycopene-apigenin" combination has a stronger anti-cancer activity than the biomolecules used separately, and it is also superior to the "lycopeneresveratrol" combination.

\section{Conclusions}

Our study demonstrated the synergistic modes of action of lycopene and apigenin in the guava fruit and the importance of the combination of these two micronutrients in pink guava in order to obtain a high anti-cancer activity.

\section{Background}

Most of the studies carried out up until now have focused primarily on the development of chemical drug products and molecules for treating cancer. However, it has been discovered that numerous plants contain cytotoxic components that are capable of inhibiting certain types of cancer $[1,2,3]$. Treatments could therefore become less invasive than the chemotherapy routinely used, and would be better tolerated by the body. 
A number of studies have indeed demonstrated the benefit of micronutrients extracted from plant biodiversity in combating cancer. These notably include carotenoids or phenolic compounds extracted from fruits and vegetables, and they have antioxidant and anti-proliferative effects on cancer cells $[4,5$, 6]. Tropical fruits, and among them the pink guava Psidium guajava L., are a source of antioxidants such as polyphenols, carotenoids and vitamins, which have known beneficial effects for human health [7].

Lycopene is one of the carotenoids found in large quantities in such fruits, and particularly in pink guava. It is a natural pigment that gives the distinctive red color to certain fruits, such as ripe tomatoes, or guava $[8,9]$. This micronutrient, which has been studied for some time now in tomatoes or watermelon, is found in larger quantities in pink guava $[10,11]$. Its beneficial effects on health, including its antioxidant properties $[12,13]$, have been demonstrated as being particularly effective for the treatment of degenerative illnesses and cardiovascular diseases [14], but also for prostate cancer [15, 16, 17, 18], breast cancer $[19,20,21]$ and for the prevention of premature aging of the skin $[22,23,24]$.

Prostate cancer, or PCa, is the second most widespread cancer in the world after skin cancer, with some 164,690 new cases and 29,430 deaths in the United States [25]. This malignant condition is highly frequent in the Caribbean Basin, including the French West Indies, with a higher mortality rate than in mainland France [26]. This may primarily be due to genetic factors, but is also thought to be due to the presence of an endocrine disruptor used in pesticides - chlordecone - traces of which have been found in foodstuffs [27]. Hormonal factors and particularly the androgen 5-alpha-dihydrotestosterone (5-alphaDHT) produced from testosterone through the action of 5-alpha-reductase, have been implicated in prostate cancer and benign prostatic hyperplasia [28].

Skin cancer, and particularly melanoma, has a high incidence among the American population, reportedly accounting for up to 91,270 new cases and 9,320 deaths in the United States [25]. This type of cancer is often triggered by exposure to UV rays, a predominant factor in the development of melanoma [29]. It has also been suggested that platelet-derived growth factor (PDGF) modulates the fibroblast microenvironment and encourages the growth of melanoma [30].

These two types of cancer, prostate cancer and melanoma, require intensive chemotherapy, which is poorly tolerated by the body and, moreover, has only transient results [31]. Lycopene has been shown to protect against prostate cancer, and its anti-proliferative and anti-androgenic properties reportedly reduce the risk of developing this tumor [32, 33, 34]. Furthermore, specific combinations of phytochemicals are thought to be more effective than individual molecules in preventing and combating certain illnesses, including cancer. This shows the need to study the synergies between active plant compounds through experiments on plant extracts.

In addition to the recognized properties of lycopene, a flavonoid of the polyphenol family - apigenin, a potent antioxidant also found in large quantities in pink guava - has been reported to have beneficial effects for combating thyroid cancer [35], prostate cancer [36], and to help prevent the development of skin cancer [37]. 
Resveratrol or trans-3,5,4'-trihydroxystilbene - another natural polyphenol found in a large variety of fruits such as grapes, berries and peanut, and also in some medicinal plants [38] - is known for its antioxidant [39] and neuroprotective properties [40, 41]. Its anti-cancer action has been reported by virtue of its involvement in numerous metabolic and cell signaling pathways, inducing apoptosis, and resistance to oxidative stress and to chronic inflammation [38].

All of these biomolecules have been studied, for the most part, separately and not as combinations. If they were combined, they might contribute new benefits as regards effective treatment options for combating certain types of cancer.

The aim of this study was therefore to evaluate, for the first time, separately and as combinations, the action of lycopene, apigenin and resveratrol on prostate and melanoma tumor cell lines.

\section{Methods}

\section{Plant materials}

Cuba Enana guava, one of the sweetest pink varieties, was obtained from the Martinique fruit orchard "Association Vergers et Jardins Tropicaux (AVJT)". One-hundred-and-seventy-five pink guavas were harvested at the "turning" stage (transition from the mature to the ripe stage) and divided into five batches. The fruits were then cut into quarters, frozen in liquid nitrogen and stored at $-80^{\circ} \mathrm{C}$ until use. For extraction, the fruits were thawed the day before at $+4^{\circ} \mathrm{C}$, weighed and ground in a Kenwood mill for 5 min at room temperature. The resulting puree was sieved $(2 \mathrm{~mm})$ and aliquots were stored at $-20^{\circ} \mathrm{C}$.

\section{Puree preparation}

The preparation of guava puree in $100 \mathrm{~g}$ portions is performed according to the technique described by [13].

\section{Reagents}

Lycopene was extracted from pink guava and purified by HPLC (>95\% purity), according to the method described by [12]. The peaks were identified by comparing their retention times with those of a commercially available tomato lycopene standard (Sigma). Crystalline apigenin $25 \mathrm{mg}$ and resveratrol $100 \mathrm{mg}$ were obtained from Sigma.

Anti-PCNA and anti-5-alpha-reductase antibodies were purchased from Santa Cruz Biotechnology (Santa Cruz, CA).

\section{Cell cultures}

Human embryonic kidney cells, HEK293T (EACC), were cultured in DMEM medium. Melanoma cell line UACC257 was from NCl-60 and was cultured in RPMI 1640. The LNCaP cell lines used in this study were obtained from IGR (Villejuif, France) and maintained in RPMI 1640 medium. All media were 
supplemented with $10 \%$ fetal calf serum, $1 \mathrm{mM}$ pyruvate, $1 \%$ nonessential amino acids, $2 \mathrm{mM}$ glutamine, $100 \mathrm{U} / \mathrm{mL}$ penicillin and $100 \mu \mathrm{g} / \mathrm{mL}$ streptomycin, and cells were maintained at $37^{\circ} \mathrm{C}$ under a humidified $5 \% \mathrm{CO}_{2}$ atmosphere. All media and cell culture supplements were obtained from Invitrogen. All cells were exposed for 24, 48 and 72 hours to increasing concentrations of lycopene $\left(0.5,5\right.$ and $\left.15 \mu \mathrm{mol} . \mathrm{L}^{-1}\right)$, apigenin $\left(20,40\right.$ and $\left.80 \mu \mathrm{mol}^{\mathrm{L}} \mathrm{L}^{-1}\right)$ and resveratrol $\left(10,50\right.$ and $\left.100 \mu \mathrm{mol} . \mathrm{L}^{-1}\right)$ separately or in combination dissolved in medium.

\section{Cell viability assay (MTT assay)}

The status of cancer cell line viability was determined by MTT (3-[4,5-dimethylthiazol-2-yl]-2,5diphenyltetrazolium bromide; thiazolyl blue) assay (Sigma). Two thousand five hundred HEK, LNCaP and UACC cells were plated on a 96 -well plate and incubated for 24,48 and 72 hours at $37^{\circ} \mathrm{C}$, under $5 \% \mathrm{CO}_{2}$, according to standard procedure. Cells were incubated with lycopene $\left(0.5,5\right.$ and $\left.15 \mu \mathrm{mol} . \mathrm{L}^{-1}\right)$, apigenin $\left(20,40\right.$ and $\left.80 \mu \mathrm{mol} . \mathrm{L}^{-1}\right)$ and resveratrol $\left(10,50\right.$ and $\left.100 \mu \mathrm{mol}^{\mathrm{L}} \mathrm{L}^{-1}\right)$ separately or in combination.

At the end of the incubation period, cells were examined under a microscope and viability was assayed using the MTT tetrazolium salt assay (Sigma): cells were incubated with $0.5 \mathrm{mg} / \mathrm{mL}$ of MTT for 1 or 2 hours and then resuspended in $100 \mu \mathrm{L}$ of DMSO. Viability was subsequently determined by measuring the absorbance at $450 \mathrm{~nm}$ with a spectrophotometer.

\section{Confocal microscopy analysis}

The confocal analysis was performed on two cell culture models: the HEK and LNCaP cell lines according to the technique described by [42]. Primary antibodies used: PCNA (1:200) and 5-alpha-reductase antibodies (1:200) (Santa Cruz).

\section{Results And Discussion}

\section{Cell viability test with Lycopene, Apigenin and Resveratrol Anti-proliferative effect of individual biomolecules}

Figure 1. Viability of untreated cell lines. (A) Untreated cells alone. (B) Untreated cells plus THF, after incubation for 24,48 and 72 hours.

Figure 2. Viability of treated cell lines. Viability of cell lines treated with Lycopene (A, B, C), Apigenin (D, E, F) and Resveratrol $(G, H, I)$, after incubation for 24,48 and 72 hours.

Under standard in vitro conditions, all the cell lines showed the normal growth expected in the absence of treatment (Fig. 1A). In vitro assays were carried out using purified lycopene extracted from guava [12], apigenin and resveratrol on HEK, LNCaP and UACC cell lines by means of the MTT (3-[4,5-dimethylthiazol2-yl]-2,5-diphenyltetrazolium bromide) assay. This assay allows rapid and sensitive quantification of proliferation and cell viability at 450nm [43]. 
Kinetics was examined at 24,48 and 72 hours according to a concentration range of the different biomolecules, recognized to obtain an optimal anti-proliferative action. Lycopene being hydrophobic, it was resuspended in THF and then diluted in culture medium. THF cytotoxicity was evaluated and under our in vitro conditions, no adverse effect on cell viability or proliferation was observed (Fig. 1B). The apigenin and resveratrol standards were diluted directly in the cell culture medium.

Cell lines were incubated at a concentration range of $0.5,5$ and $15 \mu \mathrm{mol}^{-\mathrm{L}^{-1}}$ for lycopene (Figs. $2 \mathrm{~A}$, B and C), 20, 40 and $80 \mu \mathrm{mol}^{-\mathrm{L}^{-1}}$ for apigenin (Figs. 2D, E and F) and 10, 50 and $100 \mu \mathrm{mol}^{-\mathrm{L}^{-1}}$ for resveratrol (Figs. 2G, H and I). These ranges of concentrations, for each biomolecules, were chosen according to the physiological concentrations usually used.

The results show that individual biomolecules have no effect on HEK cell proliferation. Healthy cells are therefore not the targets of these micronutrients (Fig. 2).

\section{Lycopene}

The results show that lycopene has a marked anti-cancer potential given the inhibition of the proliferation of human prostatic tumor cells (LNCaP), compared with untreated LNCaP cells (Fig. 1B). After 72 hours, treatment of LNCaP cells with $0.5,5$ and $15 \mu \mathrm{mol}^{-\mathrm{L}^{-1}}$ of lycopene shows an OD that passes from 1.3 to 1 and then to 0.6 respectively (Figs. 2A, B and C). Our results are consistent with previous reports which have suggested that this micronutrient has anti-proliferative properties [44].Indeed, it has been reported that lycopene is capable of interrupting the cell cycle by blocking cyclins such as D1, E and CDK4 [45].

However, a more moderate inhibition of proliferation of human melanoma (UACC) cells was observed in comparison to untreated UACC cells. After 72 hours, treatment of UACC cells with the same lycopene concentrations $\left(0.5,5\right.$ and $\left.15 \mu \mathrm{mol} . \mathrm{L}^{-1}\right)$ shows an OD which passes from 1.5 to 1.3 and then to 1.2 (Figs. 2A, B and C). A slight reduction in melanoma cell proliferation is therefore observed in comparison to untreated UACC cells. The literature reports the photoprotective effects of lycopene on melanoma cells [46] or its inhibitory action on platelet-derived growth factor BB (PDGF-BB) [30]. The literature does not report any direct action of lycopene on cancer cells. The results may therefore suggest that the anticancer action of lycopene on melanoma cells is indirect, possibly taking place via the signaling pathways [30]. The anti-cancer potential of lycopene is also shown by its antioxidant activity which is demonstrated by a DPPH method optimized and adapted to the carotenoid profile, and it places lycopene among the best antioxidants $[12,13]$.

Moreover the results show that in the two types of cancers studied, after $72 \mathrm{~h}$, at $15 \mu \mathrm{mol} . \mathrm{L}^{-1}$, the inhibitory effect seems saturated. Which would indicate that a concentration greater than $15 \mu \mathrm{mol} . \mathrm{L}^{-1}$ would not be significant to observe a better anti-proliferative action.

\section{Apigenin}


Apigenin has a greater anti-proliferative effect on LNCaP and UACC than lycopene. After 72 hours of treatment with apigenin at a concentration range of 20,40 and $80 \mu \mathrm{mol} . \mathrm{L}^{-1}$, a rapid drop is observed in UACC OD, passing from 1.4 to 1.3 and then to 0.6 , respectively (Figs. 2D, E and F) in comparison to untreated UACC cells which show an OD of 0.85 after 72 hours (Fig. 1A). By way of comparison, with lycopene and after 72 hours of treatment, an OD of 1.2 is obtained. These results are in agreement with those of studies on the effect of apigenin on the cell cycle of keratinocytes in the context of skin tumorigenesis. This flavonoid inhibits the cell cycle by interrupting it at the G2/M stage [47] or by inhibiting apoptosis of keratinocytes exposed to UVB [37]. Its action on keratinocytes has also been reported in the inhibition of mTOR signaling involved in the development of skin cancer [48].

As regards $L N C a P$, a significant decrease in cell proliferation is also observed, with the OD dropping from 1 to 0.9 and then to 0.3 (Figs. 2D, E and F) after 72 hours. This decrease is twofold in comparison to treatment with lycopene which shows an OD of 0.6 after 72 hours.

This inhibition of human prostatic tumor cell proliferation by apigenin, acting like an estrogen, is thought to be partially mediated by ERB estrogen receptor [49]. In a similar way, blocking of IKKa kinase activity [50] or inactivation of Akt by apigenin is thought to induce apoptosis of prostate cancer cells [51].

\section{Resveratrol}

According to our results, the anti-proliferative action of resveratrol on UACC is slightly higher than with lycopene, but lowers than that of apigenin.

After 72 hours, treatment of UACC with 10,50 and $100 \mu \mathrm{mol}^{-1} \mathrm{~L}^{-1}$ of resveratrol shows an OD which drops from 1.4 to 1.2 and then to 1 , respectively (Figs. $2 \mathrm{G}, \mathrm{H}$ and I) in comparison to untreated UACC cells. This inhibition is lower than that obtained with apigenin where, after 72 hours of treatment and at the highest physiological concentration $\left(80 \mu \mathrm{mol}^{\mathrm{L} \mathrm{L}^{-1}}\right)$, a very low OD of 0.6 is obtained (Fig. 2F). However, the antiproliferative effects of resveratrol are slightly higher to those of lycopene which, after 72 hours at $15 \mu \mathrm{mol}^{-\mathrm{L}^{-1}}$, showed an OD of 1.2 (Fig. 2C). Resveratrol has been reported to have anti-proliferative and apoptotic effects on human melanoma cell lines $[52,53]$. Furthermore, it is thought to inhibit the a-MSH hormone signaling involved in melanoma invasiveness [54].

As regards $L N C a P$, resveratrol has a low anti-proliferative activity. After 72 hours, treatment at resveratrol concentrations of 10,50 and $100 \mu \mathrm{mol}^{-\mathrm{L}^{-1}}$, shows an $\mathrm{OD}$ of $0.75,0.9$ and 0.9 respectively (Figs. $2 \mathrm{G}, \mathrm{H}$ and I), while untreated LNCaP after 72 hours shows an OD of 0.75 (Fig. 1A). This is a very low inhibition of proliferation compared with lycopene on LNCaP which, after 72 hours of treatment, gives an OD of 0.6 (Fig. 2C); or better still with apigenin which gives an OD of 0.3 (Fig. 2F). A number of studies have in the past reported on resveratrol in the context of the prevention of prostate cancer by virtue of its antiandrogenic action in vivo on transgenic mice developing adenocarcinoma of the prostate (TRAP), on transgenic adenocarcinoma mouse prostate (TRAMP), and on prostate cancer xenograft models $[55,56$, 57]. However, some studies have made it possible to observe the in vitro effects of this polyphenol on human prostate cancer cell lines in which a more significant inhibition of proliferation of LNCaP and PC- 
3M-MM2 was observed but for a longer incubation time, i.e. 96 hours, in the presence of resveratrol [58, $59,60]$.

The results of the different treatments set out in our study show that apigenin has the most marked antiproliferative effect on both LNCaP and UACC, followed by lycopene with a stronger inhibitory activity on LNCaP than on UACC, and lastly resveratrol (Fig. 2).

These results are in agreement with the literature in relation to the effects of lycopene and apigenin on prostate cancer cells. However, not many studies have been carried out on the effects of lycopene on melanoma and, in our study, it was found to inhibit cell proliferation to a certain extent. As regards resveratrol, it does not appear to have the strong anti-cancer potential of the other two biomolecules which are naturally combined in pink guava. It is therefore of interest to study these biomolecules in the form of combinations, something that has never been done to date.

\section{Anti-proliferative effect of combined biomolecules}

Figure 3. Viability of cell lines treated with a combination of micronutrients. Cell lines treated with lycopene-apigenin (A, B and C) and with lycopene-resveratrol (D, E and F) after 24, 48 and 72 hours of incubation.

In the light of the results obtained previously, varying concentrations of lycopene (0.5-5 and $\left.15 \mu \mathrm{mol} . \mathrm{L}^{-1}\right)$ were combined with the most effective concentration of apigenin and resveratrol, i.e. $80 \mu \mathrm{mol} . \mathrm{L}^{-1}$ and $100 \mu \mathrm{mol}^{\mathrm{L}} \mathrm{L}^{-1}$, respectively. Two combinations which had never previously been studied were thus prepared: "lycopene - apigenin" and "lycopene - resveratrol".

Regardless of how the biomolecules were combined, they showed no effect on HEK proliferation (Fig. 3). This confirms the results obtained from the study of individual micronutrients on these healthy cells.

\section{Lycopene and Apigenin}

For the "lycopene-apigenin" combination, the highest apigenin concentration was chosen, i.e. $80 \mu \mathrm{mol} . \mathrm{L}^{-}$ 1.

As regards UACC, the combined effect of "lycopene-apigenin" causes a sharp drop in cell growth after 24 hours of incubation, regardless of the lycopene concentration, with OD dropping from 0.6 to 0.3. However, after 48 hours of incubation, a slight increase is observed. At different lycopene concentrations, after 72 hours of incubation, a starting OD of 0.6 is obtained with $0.5 \mu$ mol. $\mathrm{L}^{-1} ; 1.1$ with $5 \mu \mathrm{mol} . \mathrm{L}^{-1}$ and 0.9 with $15 \mu \mathrm{mol}^{-L^{-1}}$ (Figs. 3A, B and C). This sharp decrease obtained with the combination after 24 hours of incubation is not observed with individual biomolecules. An incubation of 72 hours is required to reach an OD of 0.6 with $80 \mu \mathrm{mol}^{\mathrm{L}} \mathrm{L}^{-1}$ apigenin (Fig. $2 \mathrm{~F}$ ) and $15 \mu \mathrm{mol} . \mathrm{L}^{-1}$ lycopene is required to reach the lowest OD of 1.2 for UACC after 72 hours of incubation (Fig. 2C). This is therefore a very effective combination for inhibiting cell proliferation after 24 hours. 
As regards LNCaP, the "lycopene-apigenin" combination also causes a decrease in cell proliferation after 24 hours of incubation, at a lycopene concentration of $5 \mu \mathrm{mol} . \mathrm{L}^{-1}$, with the OD dropping from 0.5 to 0.3 and reaching a plateau at 0.5 (Figs. 3A, B and C). This significant decrease was not obtained with individual biomolecules. 72 hours were required to obtain an OD of 0.6 with the highest concentration of lycopene, i.e. $15 \mu \mathrm{mol} . \mathrm{L}^{-1}$ (Fig. $2 \mathrm{C}$ ), and an OD of 0.3 with $80 \mu \mathrm{mol} . \mathrm{L}^{-1}$ apigenin (Fig. 2F).

The addition of apigenin to lycopene significantly increases the anti-cancer effect by almost completely inhibiting the proliferation of prostate cancer and melanoma cells. This combination is considerably more effective than biomolecules used separately.

\section{Lycopene and Resveratrol}

For the "lycopene-resveratrol" combination, the highest resveratrol concentration was chosen, i.e. $100 \mu \mathrm{mol} \cdot \mathrm{L}^{-1}$.

This combination shows a marked inhibition of LNCaP cell proliferation. After 72 hours of incubation, the OD passes from 1.5 with $0.5 \mu \mathrm{mol} . \mathrm{L}^{-1}$ lycopene to 0.6 with 5 and $15 \mu \mathrm{mol}^{-\mathrm{L}^{-1}}$ (Figs. 3D, E and F).

This inhibition is far more effective when compared to the inhibition obtained with lycopene on its own since after 72 hours of incubation, an OD of 0.6 is obtained at the highest lycopene concentration of $15 \mu \mathrm{mol} . \mathrm{L}^{-1}$ (Fig. $2 \mathrm{C}$ ), while this level is obtained at the $5 \mu \mathrm{mol} . \mathrm{L}^{-1}$ lycopene concentration for the combination. A similar phenomenon is observed with $100 \mu \mathrm{mol} . \mathrm{L}^{-1}$ resveratrol on its own, wherein after 72 hours of incubation, an OD of just 1 is obtained (Fig. 2F).

As regards melanoma cells (UACC), after 72 hours of incubation, the combination shows an OD that passes from 1 with $0.5 \mu \mathrm{mol} . \mathrm{L}^{-1}$ lycopene to 0.8 with $5 \mu \mathrm{mol} . \mathrm{L}^{-1}$ and 1.2 with $15 \mu \mathrm{mol} . \mathrm{L}^{-1}$ (Figs. 3D, E and F). Inhibition is therefore obtained with 0.5 and $5 \mu \mathrm{mol}^{-\mathrm{L}^{-1}}$ lycopene when combined with resveratrol, and is far more significant compared to the treatment of UACC with 0.5 and $5 \mu \mathrm{mol} . \mathrm{L}^{-1}$ lycopene on its own. In contrast, poor inhibition is obtained with $15 \mu \mathrm{mol} . \mathrm{L}^{-1}$ lycopene in the combined form, which is identical to that obtained with $15 \mu \mathrm{mol} . \mathrm{L}^{-1}$ lycopene on its own (Fig. $2 \mathrm{C}$ ).

With resveratrol on its own, at $100 \mu \mathrm{mol}^{\mathrm{L}} \mathrm{L}^{-1}$, an OD of 1 was obtained, while when combined with lycopene at $5 \mu \mathrm{mol} . \mathrm{L}^{-1}$, proliferation is far more effectively inhibited and an OD of 0.8 is obtained (Fig. 2E). It is therefore evident that the combination lycopene $5 \mu \mathrm{mol} . \mathrm{L}^{-1}$ with resveratrol $100 \mu \mathrm{mol} . \mathrm{L}^{-1}$ is the most effective for significantly reducing melanoma cell proliferation.

\section{Comparison of Lycopene and Apigenin / Lycopene and Resveratrol combinations}

The "Iycopene-apigenin" combination on the melanoma cell line UACC and prostate cancer cell line LNCaP, which has a marked anti-proliferative effect after 24 hours compared to the "lycopeneresveratrol" combination, therefore appears to be significantly more effective, and for this reason would 
be the best combination for achieving effective inhibition. Lycopene in combination with apigenin indeed blocks cell proliferation whereas when in combination with resveratrol, the proliferation curve appears to continue except for the lycopene concentration of $5 \mu \mathrm{mol} . \mathrm{L}^{-1}$. This would appear to be the ideal and optimum concentration for inhibition in combination with resveratrol. It is possible that at this concentration, lycopene does not compete with resveratrol, while this is not the case when the lycopene concentration is $15 \mu \mathrm{mol} . \mathrm{L}^{-1}$. By contrast, the $0.5 \mu \mathrm{mol} . \mathrm{L}^{-1}$ concentration of lycopene appears not to be sufficient to trigger significant inhibition in the combination with resveratrol.

\section{Confocal microscopy experiments}

\section{Anti-proliferative assays using anti-PCNA and lycopene}

Figure 4. Confocal evaluation of cell proliferation using anti-PCNA antibody. Evaluation of cell proliferation using anti-PCNA antibody on HEK cells not treated with lycopene (A) and treated with

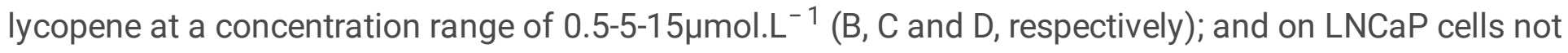
treated with lycopene $(E)$ and treated with lycopene at a concentration range of $0.5-5-15 \mu \mathrm{mol}^{-\mathrm{L}^{-1}}(\mathrm{~F}, \mathrm{G}$ and $\mathrm{H}$, respectively) after 72 hours of incubation.

Confocal immunofluorescence was used to evaluate HEK and LNCaP cell proliferation in the presence (Figs. 4B, C, D, F, G and H) and absence (Figs. 4A and E) of different lycopene concentrations (0.5-5 and $15 \mu \mathrm{mol} . \mathrm{L}^{-1}$ ) after 72 hours, using an anti-PCNA antibody (nuclear labeling).

The results show that healthy HEK cells treated with lycopene exhibit identical nuclear labeling compared to untreated HEK cells, regardless of lycopene concentration (Figs. 4B, C and D). Lycopene therefore has no effect on HEK proliferation in comparison with untreated cells (Fig. 4A). This confirms the MTT assay results previously obtained.

Confocal microscopy was able to demonstrate a reduction in the proliferation of the prostate cancer cell

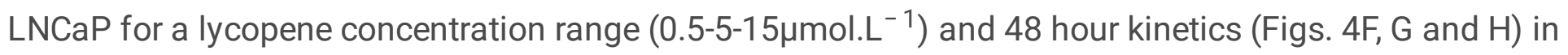
comparison with untreated cells (Fig. 4E). This results in a reduction in the LNCaP nuclear signal with increasing amounts of lycopene until almost complete extinction of the signal is obtained at $15 \mu \mathrm{mol} . \mathrm{L}^{-1}$ lycopene (Fig. 4H).

This pigment therefore has no anti-proliferative effect on healthy cells and acts specifically on prostate cancer cells.

\section{Anti-androgenic effects with anti-a-reductase with lycopene, apigenin and resveratrol separately}

Figure 5a. Confocal evaluation of anti-androgenic action, using anti-a-reductase, of lycopene, apigenin and resveratrol on LNCaP cells. Untreated LNCaP (A), LNCaP incubated with lycopene $15 \mu \mathrm{mol} . \mathrm{L}^{-1}(\mathrm{~B})$, 
LNCaP incubated with apigenin $80 \mu \mathrm{mol}^{-\mathrm{L}^{-1}}$ (C), and LNCaP incubated with resveratrol $100 \mu \mathrm{mol} . \mathrm{L}^{-1}$ (D) after incubation for 72 hours.

Numerous studies have shown that the androgen 5-alpha-DHT, which is produced from testosterone through the action of the enzyme 5 -alpha-reductase, is responsible for prostate cancer and benign prostatic hyperplasia [61].

Confocal microscopy was able to show cytoplasmic labeling of this 5-alpha-reductase enzyme on untreated LNCaP cells (Fig. 5a A) and LNCaP cells treated with the biomolecules at their optimum concentrations, namely $15 \mu \mathrm{mol} . \mathrm{L}^{-1}$ lycopene (Fig. 5a B), $80 \mu \mathrm{mol} . \mathrm{L}^{-1}$ apigenin (Fig. $5 \mathrm{a} \mathrm{C}$ ) and $100 \mu \mathrm{mol}^{-\mathrm{L}^{-1}}$ resveratrol (Fig. 5a D) after 72 hours, using an anti-5-alpha-reductase antibody.

The results show that untreated LNCaP cells exhibit cytoplasmic labeling indicating the presence of the enzyme (Fig. 5a A) which is comparable to LNCaP cells treated with $100 \mu \mathrm{mol}^{-\mathrm{L}^{-1}}$ resveratrol (Fig. $5 \mathrm{a} \mathrm{D}$ ). This suggests that resveratrol has no effect on 5-alpha-reductase and therefore no anti-androgenic effect, a result that has never been reported before.

By contrast, lycopene drastically reduces the cytoplasmic labeling of LNCaP cells (Fig. 5a B), and apigenin completely eliminates the signal (Fig. 5a C). Lycopene therefore has an anti-androgenic effect by inhibiting the expression of 5 -alpha-reductase, a result which has previously been reported and is confirmed here $[32,62,63]$.

Furthermore, our results show a particularly targeted action of apigenin on the expression of the enzyme, a result that has not yet been reported in the literature since only its anti-proliferative and anti-apoptotic effects have been described $[64,51,65,50,66]$.

Lycopene and apigenin, when used separately, thus exhibit this inhibitory property for 5-alpha-reductase and therefore, implicitly, for 5-alpha-DHT, which is responsible for the development of prostate cancer.

In light of these results, it was considered of interest to evaluate the combined action of these biomolecules on the expression of 5-alpha-reductase.

\section{Anti-androgenic effects, using anti-a-reductase, of lycopene-apigenin and lycopene-resveratrol combinations}

Figure 5b. Confocal evaluation of anti-androgenic effects, using anti-a-reductase, of lycopene-apigenin and lycopene-resveratrol combinations on LNCaP cells. LNCaP incubated with the lycopene/apigenin $80 \mu \mathrm{mol} . \mathrm{L}^{-1}$ combination (A), and LNCaP incubated with the lycopene $15 \mu \mathrm{mol} . \mathrm{L}^{-1} /$ resveratrol $100 \mu$ mol.L ${ }^{-1}$ combination (B) after incubation for 72 hours.

Two combinations have been prepared for the first time as anti-androgenic treatment on LNCaP for 72 hours, using an anti-5-alpha-reductase antibody. They are combinations at the highest concentrations of

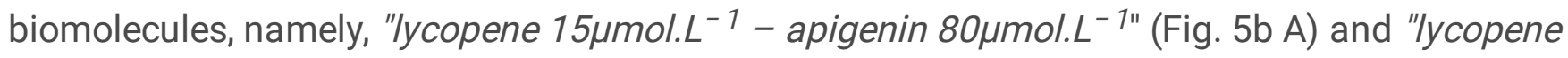


$15 \mu \mathrm{mol} . \mathrm{L}^{-1}$ - resveratrol $100 \mu \mathrm{mol} . \mathrm{L}^{-1}$ "(Fig. $5 \mathrm{~b} \mathrm{~B}$ ). The untreated LNCaP cells exhibit the expected cytoplasmic labeling (Fig. 5a A).

\section{Lycopene and Apigenin}

The results show that there is no cytoplasmic labeling of LNCaP cells with the "lycopene $15 \mu \mathrm{mol} . \mathrm{L}^{-1}$ apigenin $80 \mu \mathrm{mol} . \mathrm{L}^{-1}$ " combination (Fig. 5b A) compared to untreated LNCaP cells (Fig. 5a A). Indeed, this combination completely inhibits the expression of the enzyme 5-alpha-reductase, and thereby also inhibits the signaling pathway for the production of 5-alpha-DHT. This result confirms the results previously obtained for the biomolecules separately (Figs. 5a B and C), with in addition an improvement in the anti-androgenic action of lycopene by virtue of the coupling with apigenin.

\section{Lycopene and Resveratrol}

The results show weak cytoplasmic labeling of LNCaP cells with the "lycopene $15 \mu \mathrm{mol} . \mathrm{L}^{-1}$ - resveratrol $100 \mu$ mol. $\mathrm{L}^{-1}$ " combination (Fig. 5b B) in comparison with untreated LNCaP cells (Fig. 5a A). Indeed, this combination partially inhibits the expression of the enzyme 5-alpha-reductase and therefore additionally the production of 5-alpha-DHT. This observed inhibition is due solely to the addition of lycopene, and is comparable to the inhibition obtained by lycopene alone on LNCaP cells (Fig. 5a B).

\section{Comparison of Lycopene and Apigenin / Lycopene and Resveratrol}

The "lycopene - apigenin" combination, on the prostate cancer cell line LNCaP exhibits a very high antiandrogenic activity compared to the "lycopene - resveratrol" combination. Indeed, lycopene and apigenin exhibit anti-5-alpha-reductase properties, unlike resveratrol. Furthermore, the combination of lycopene and apigenin enhances the intrinsic properties of each of these biomolecules without nevertheless entering into competition, thereby allowing optimum inhibition of the action of the enzyme 5-alpha-reductase.

Resveratrol, which has only a very low anti-androgenic activity or none whatsoever, is of no benefit when combined with lycopene. This combination basically amounts to the intrinsic activity of lycopene on its own.

The "lycopene - apigenin" combination therefore appears to be the best possible combination for achieving total inhibition of the expression of 5-alpha-reductase.

\section{Conclusions}

The aim of our study was to compare and evaluate, for the first time, the individual action and the combined action of lycopene extracted from Psidium guajava $L$., and of apigenin and resveratrol, on prostate cancer cell lines and melanoma cell lines. This was initially performed by demonstrating the anti-proliferative action of these biomolecules by means of the MTT assay on both cancer cell lines. The anti-proliferative effect was observed to different degrees, with prevalence for apigenin, followed by 
lycopene and then resveratrol separately, and a more targeted inhibition on LNCaP cells for lycopene. Furthermore, these results were confirmed by confocal microscopy, wherein interruption of the proliferation of LNCaP cells was obtained. As regards combinations of these biomolecules, it is evident that the combination of the two pink guava micronutrients, lycopene and apigenin, and their synergistic modes of action in the guava fruit are responsible for a high anti-cancer activity.

Finally, this work shows the importance of synergistic effects of biomolecules and the need to consume the fruit or the derived products like pure juices, nectars, jams or jellies, with all its micronutrients instead of consuming them separately. This synergy allows obtaining a better anti-cancer performance.

\section{Declarations}

\section{Acknowledgments}

We would like to thank the iBiTec-S Institute of the Atomic Energy Commission, Saclay, the fruit orchard "Association Vergers et Jardins Tropicaux (AVJT)", and CIRAD (Centre de coopération internationale en recherche agronomique pour le développement).

\section{Author's contributions}

FP, OF and EJS conceived and designed this research. OF and RM collected guavas and prepared the extractions. FP and RM performed guava puree and Lycopene extraction. FP and AW operated the cell experiments. EJS and FP conducted the processing and analysis of MTT and Confocal data. FP and EJS drafted the manuscript. All authors read and approved the final manuscript.

\section{Funding}

This work was financially supported by "Association de Recherche en Epidémiologie et Biodiversité" (AREBio), the "Collectivité Territoriale de Martinique (CTM) on Research Project FEDER N 31455.

\section{Availability of data and materials}

All data generated or analyzed during this study are included in the manuscript.

\section{Ethics approval and consent to participate}

Not applicable.

\section{Consent for publication}

Not applicable.

\section{Competing interests}

The authors declare no conflict of interest. 


\section{Author details}

${ }^{1}$ Research Group BIOSPHERES, Campus de Schœlcher, Université des Antilles, BP 7207, 97275

Schœlcher Cedex, Martinique, France. ${ }^{2}$ SPI, LERI, Centre CEA, Gif-sur-Yvette 91191 Cedex, France.

\section{References}

1. Begum S, Hassan SI, Siddiqui B.S, F, Ghayur M.N,. Gilani A H. Triterpenoids from the leaves of Psidium guajava. 2002; 61: 399-403. doi: 10.1016/S0031-9422(02)00190-5

2. Deo A and Shastri NV. Purification and characterization of polygalacturonase-inhibitory proteins from Psidium guajava Linn. (guava) fruit. Plant Science. 2003; 164 (2): 147-156. doi: 10.1016/S0168-9452(02)00337-0

3. Joseph B and Priya RM. Phytochemical and Biopharmaceutical Aspects of Psidium guajava (L.) Essential Oil: A Review. Research Journal of Medicinal Plant. 2011. doi: 10.3923/rjmp.2011.432.442

4. Charepalli, V, Reddivari L, Radhakrishnan S, Vadde R, Agarwal R, Vanamala JKP. Anthocyanincontaining purple-fleshed potatoes suppress colon tumorigenesis viaelimination of colon cancer stem cells. The Journal of nutritional biochemistry. 2015; 26(12):1641-9. doi:

10.1016/j.jnutbio.2015.08.005

5. Charepalli V, Reddivari L, Vadde R, Walia S, Radhakrishnan S, Vanamala JK P. Eugenia jambolana (Java Plum) Fruit Extract Exhibits Anti-Cancer Activity against Early Stage Human HCT-116 Colon Cancer Cells and Colon Cancer Stem Cells.Cancers. 2016; 8(3). doi: 10.3390/cancers8030029

6. Ramos-Bueno RP, Romero-Gonzalez R, Gonzalez-Fernandez MJ and Guil-Guerrero JL. Phytochemical composition and in vitro anti-tumour activities of selected tomato varieties. J Sci Food Agric. 2017; 97(2):488-496. doi: 10.1002/jsfa.7750

7. Alvarez-Suarez J, Giampieri F, Gasparrini M, Mazzoni L, Forbes-Hernández T, Afrin S et al. Guava ( Psidium guajava L . cv. Red Suprema) Crude Extract Protect Human Dermal Fibroblasts against Cytotoxic Damage Mediated by Oxidative Stress. Plant Foods for Human Nutrition. 2018; 73(1): 1824. doi: $10.1007 / \mathrm{s} 11130-018-0657-2$

8. Jarquín-Enríquez L, Mercado-Silva EM, Maldonado JL, Lopez-Baltazar J. Lycopene content and color index of tomatoes are affected by the greenhouse cover. Scientia Horticulturae. 2013; 155: 43-48. https://doi.org/10.1016/j.scienta.2013.03.004

9. Shukla S, Kushwaha R, Singh M, Saroj R, Puranik V, Agarwal R, Kaur D. Quantification of bioactive compounds in guava at different ripening stages. Food Research, 2021; 5(3):183-189. doi : 26656/fr.2017.5(3).554

10. Perkins-Veazie P, Collins JK, Pair SD, Roberts W. Lycopene content differs among red-fleshed watermelon cultivars. Journal of the Science of Food and Agriculture. $2001 ; 81(10)$ : 983-987. doi : $10.1002 / \mathrm{jsfa} .880$

11. Lecerf JM Lecerf. Tomato lycopene and cardiovascular prevention. Phytothérapie. 2006; 4: 34-39. doi : 10.1007/s10298-006-0132-3 
12. Priam F, Marcelin O, Marcus R, Jô LF, Smith-Ravin EJ. Lycopene extraction from Psidium guajava L. and evaluation of its antioxidant properties using a modified DPPH test. IOSR Journal of Environmental Science, Toxicology and Food Technology. 2017; 11(4): 67-73. https://www.doi.org/10.9790/2402-1104016773

13. http://www.iosrjournals.org/iosr-jestft/papers/vol11-issue\%204/Version-1/K1104016773.pdf

14. Marcelin O, Mazaloubeaud C, Priam F, Marcus R, Belloir F, Vrabié V, Smith-Ravin An integrative analytical study of the functional and antioxidant properties of selected varieties of pink guava Psidium guajava L. IOSR Journal of Environmental Science, Toxicology and Food Technology. 2017; 11(9): 57-67. doi: 10.9790/2402-1109015767.

15. http://www.iosrjournals.org/iosr-jestft/papers/vol11-issue\%209/Version-1//1109015767.pdf

16. Kong KW, Khoo HE, Prasad KN, Ismail A Tan C-P, Rajab NF. Revealing the power of the natural red pigment lycopene. Molecules. 2010; 15(2): 959-87. doi: 10.3390/molecules15020959

17. Inserra P. Dietary intake of lycopene and risk of prostate cancer. Wild-Type Food in Health Promotion and Disease Prevention. 2008; 463-467. https://link.springer.com/chapter/10.1007/978-1-59745330-1_31

18. Lee LK., Foo KY. An appraisal of the therapeutic value of lycopene for the chemoprevention of prostate cancer: A nutrigenomic approach. Food Research International. 2013; 54:1217-1228. doi: 10.1016/j.foodres.2013.03.027

19. Pereira Soares NDC, Teodoro AJ, Oliveira FL, Takiya CM, Junior AP, Nasciutti LE. Lycopene induce apoptosis in human prostate cells and alters the expression of Bax and Bcl-2 genes. LWT - Food Science and Technology. 2014; 59 (2):1290-1297. doi: 10.1016/j.Iwt.2014.04.028

20. Wang Y, Cui R, Xiao Y, Fang J, Xu Q. Effect of Carotene and Lycopene on the Risk of Prostate Cancer: A Systematic Review and Dose-Response Meta-Analysis of Observational Studies. PLoS ONE. 2015; 10(9): p.e0137427. doi:10.137/pone.0137427

21. Gloria NF, Soares N, Brand C, Oliveira FL, Borojevic R, Teodoro AJ. Lycopene and Beta-carotene Induce Cell-Cycle Arrest and Apoptosis in Human Breast Cancer Cell Lines. Anticancer Research. 2014; 34(3): 1377-1386. https://ar.iiarjournals.org/content/anticanres/34/3/1377.full.pdf

22. Peng SJ, Li J, Zhou Y, Tuo M, Qin XX, Yu Q et al. In vitro effects and mechanisms oflycopene in MCF7 human breast cancer cells. Genetics and molecular research. 2017; 16(2). doi:

10.4238 /gmr16029434

23. Jain A, Sharma G, Kushwah V, Thakur K. Ghoshal G, Singh B. Fabrication and functional attributes of lipidic nanoconstructs of lycopene: An innovative endeavour for enhanced cytotoxicity in MCF-7 breast cancer cells. Colloids and Surfaces B: Biointerfaces. 2017; (152): 482-491. doi:10.1016/j.colsurfb.2017.01.050

24. Wright TI, Spencer JM, Flowers FP. Chemoprevention of nonmelanoma skin cancer. Journal of the American Academy of Dermatology. 2006; 54(6):933-46. doi:10.1016/j.jaad.2005.08.062

25. Ascenso A, Ribeiro H, Marques HC, Oliveira H, Santos C, Simões S. Chemoprevention of photocarcinogenesis by lycopene. Experimental dermatology. 2014; .23(12):874-8. 
https://doi.org/10.1111/exd.12491

26. Cefali LC, Souza-Moreira TM, Corrêa MA, Salgado HRN, Isaac VLB. Development and evaluation of an emulsion containing lycopene for combating acceleration of skin aging. Brazilian Journal of Pharmaceutical Sciences. 2015; 51(3): 579-590. doi: 10.1590/S1984-82502015000300010

27. Key Statistics for Prostate Cancer. ACS. 2018. https://www.cancer.org/cancer/prostatecancer/about/key-statistics.html

28. Multigner L, Ndong JR, Giusti A, Romana M, Delacroix-Maillard H, Cordier S, Jégou B, Thome JP, Blanchet P. Chlordecone Exposure and Risk of Prostate Cancer. J Clin Oncol. 2010; 28:3457-3462. doi: $10.1200 / J C 0.2009 .27 .2153$

29. Multigner L, Cordier S, Kadhe PI, Huc-Terki F, Blanchet P, Bataille H et al. Pollution par le chlordécone aux Antilles Quel impact sur la santé de la population? Environnement, Risques et Santé. 2007 ; 6 (6): 405-7. doi : 1684/ers.2007.0121

30. Brawley OW MD. Prostate cancer screening: clinical applications and challenges. Urologic Oncology: Seminars and Original Investigations. 2004; 22 (4): 353-357. doi:10.1016/j.urolonc.2004.04.014

31. Miller A J and Mihm, MC. Mechanisms of disease N Engl J Med .2006; 355:51-65.

32. Chiang HS, Wu WB, Fang JY, Chen DF, Chen BH et al. Lycopene inhibits PDGF-BB-induced signaling and migration in human dermal fibroblasts through interaction with PDGF-BB. Life Sciences. 2007; 81 (21-22): 1509-1517.

33. Eichholz A, Ferraldeschi R, Attard G, de Bono JS. Putting the brakes on continued androgen receptor signaling in castration-resistant prostate cancer. Molecular and Cellular Endocrinology. 2012; 360: 68-75. doi:10.1016/j.mce.2011.09.038

34. Wertz K, Siler U, Goralczyk Lycopene: modes of action to promote prostate health. Archives of Biochemistry and Biophysics. 2004; 430 (1): 127-134. doi:10.1016/j.abb.2004.04.023

35. Wei MY and Giovannucci EL. Lycopene, Tomato Products, and Prostate Cancer Incidence: A Review and Reassessment in the PSA Screening Era. Journal of Oncology. 2012; 2012: 271063. doi:10.1155/2012/271063

36. Thapa D and Ghosh R. Antioxidants for prostate cancer chemoprevention: Challenges and opportunities. Biochemical Pharmacology. 2012; 83 (10): 1319-1330. doi:10.1016/j.bcp.2011.12.027

37. Shan S, Shi J, Yang P, Jia B, Wu H, Zhang X et al. Apigenin Restrains Colon Cancer Cell Proliferation via Targeted Blocking of Pyruvate Kinase M2-Dependent Glycolysis. Journal of agricultural and food chemistry. 2017; 65(37): 8136-8144. doi: 10.1021/acs.jafc.7b02757

38. Shukla S, Maclennan GT, Fu P, Gupta S. Apigenin attenuates insulin-like growth factor-I signaling in an autochthonous mouse prostate cancer model. Pharmaceutical Research. 2012; 29(6):1506-17. doi:10.1007/s11095-011-0625-0

39. Abu-Yousif AO, Smith KA, Getsios S, Green KJ, Van Dross RT, Pelling JC. Enhancement of UVBInduced Apoptosis by Apigenin in Human Keratinocytes and Organotypic Keratinocyte Cultures. Cancer Res. 2008; 68(8): 3057-65. doi:1158/0008-5472.CAN-07-2763 
40. Gambini J, Inglés M, Olaso G, Lopez-Grueso R, Bonet-Costa V, Gimeno-Mallench L et al. Properties of Resveratrol: In Vitro and In Vivo Studies about Metabolism, Bioavailability, and Biological Effects in Animal Models and Humans. Oxidative Medicine and Cellular Longevity. 2015; 2015. .doi: $10.1155 / 2015 / 837042$

41. Alonso AM, Domínguez C, Guillén DA, Barroso CG. Determination of antioxidant power of red and white wines by a new electrochemical method and its correlation with polyphenolic content. Journal of agricultural and food chemistry. 2002; 50(11):3112-5. doi: 10.1021/jf0116101

42. Robb EL and Stuart JA. trans-Resveratrol as A Neuroprotectant. Molecules. 2010; 15(3): 1196-1212. doi: 10.3390/molecules15031196

43. Richard T, Pawlus AD, Iglésias ML, Pedrot E, Waffo-Teguo P, Mérillon JM, Monti JP. Neuroprotective properties of resveratrol and derivatives. Annals of the New York Academy of Sciences, January. 2011; 1215: 103-8. doi: 10.1111/j.1749-6632.2010.05865.x

44. Allard B, Priam F, Deshayes F, Ducancel F, Boquet D, Wijkhuisen A, Couraud JY. Electroporation-aided DNA Immunization Generates Polyclonal Antibodies against the Native Conformation of Human Endothelin B Receptor. DNA Cell Biol. 2011; 30(9):727-37.doi: 10.1089/dna.2011.1239

45. Yu H and Huang Q, Investigation of the cytotoxicity of food-grade nanoemulsions in Caco-2 cell monolayers and HepG2 cells. Food Chem. 2013; 141: 29-33. .doi: 10.1016/j.foodchem.2013.03.009

46. Teodoro AJ, Oliveira FL, Martins NB, de Azevedo Maia G, Martucci RB, Borojevic R. Effect of lycopene on cell viability and cell cycle progression in human cancer cell lines. Cancer Cell International. 2012; 12(1):36. doi: 10.1186/1475-2867-12-36.

47. Ivanov NI, Cowell SP, Brown P, Rennie PS, Guns ES, Cox ME. Lycopene differentially induces quiescence and apoptosis in androgen-responsive and -independent prostate cancer cell lines. Clinical Nutrition. 2007; 26(2): 252-263. doi:10.1016/j.clnu.2007.01.002

48. Cooperstone JL, Tober KL, Riedl KM, Teegarden MD, Cichon MJ, Francis DM et al. Tomatoes protect against development of UV-induced keratinocyte carcinoma via metabolomic alterations.Scientific 2017; 7: 5106. doi:10.1038/s41598-017-05568-7

49. Lepley DM, Li B, Birt DF and Pelling JC. The chemopreventive flavonoid apigenin induces G2/M arrest in keratinocytes. 1996; 17 (11): 2367-2375. doi: 10.1093/carcin/17.11.2367

50. Bridgeman BB, Wang P, Ye Boping, Pelling JC, Volpert OV, Tong X, Inhibition of mTOR by apigenin in UVB-irradiated keratinocytes: A new implication of skin cancer prevention. Cell Signal. 2016; 28(5): 460-468. doi:10.1016/j.cellsig.2016.02.008

51. Mak P, Leung YK, Tang WY, Harwood C, Ho SM. Apigenin Suppresses Cancer Cell Growth through ERB1. Neoplasia. 2006; 8: 896-904. doi: 10.1593/neo.06538

52. Shukla S, Kanwal R, Eswar Shankar, Manish Datt, Mark R. Chance, Pingfu Fu et al. Apigenin blocks IKKa activation and suppresses prostate cancer Progression. Oncotarget. 2015; 6 (31): 31216-32

53. Parminder Kaur1, Sanjeev Shukla1 and Sanjay Gupta Plant flavonoid apigenin inactivates Akt to trigger apoptosis in human prostate cancer: an in vitro and in vivo study .Carcinogenesis. 2008; 29 (11): 2210-2217. doi:10.1093/carcin/bgn201 
54. Larrosa M, Tomas-Barberan FA, Espin JC. Grape Polyphenol Resveratrol and the Related Molecule 4Hydroxystilbene Induce Growth Inhibition, Apoptosis, S-Phase Arrest, and Upregulation of Cyclins A, E, and B1 in Human SK-Mel-28 Melanoma Cells. Agric. Food Chem. 2003; 51(16): 4576-4584. doi: 10.1021/jf030073c

55. Aggarwal, Bharat B ; Bhardwaj, Anjana ; Aggarwal, Rishi S ; Seeram, Navindra P ; Shishodia, Shishir ; Takada, Yasunari. Role of resveratrol in prevention and therapy of cancer: preclinical and clinical studies. Anticancer Research. 2004; 24(5A): 2783-840

56. Chen YJ, Chen YY, Lin YF, Hu HY, Liao HF. Resveratrol Inhibits Alpha-Melanocyte-Stimulating Hormone Signaling, Viability, and Invasiveness in Melanoma Cells. Evidence-Based Complementary and Alternative Medicine. 2013; 2013.doi: 10.1155/2013/632121

57. Harper CE, Patel BB, Wang J, Arabshahi A, Eltoum IA, Lamartiniere CA. Resveratrol suppresses prostate cancer progression in transgenic mice. 2007; 28(9): 1946-1953. doi:10.1155/2013/632121

58. Seeni A, Takahashi S, Takeshita K, Tang M, Sugiura S, Sato SY et al. Suppression of prostate cancer growth by resveratol in the transgenic for adenocarcinoma of prostate (TRAP) model. Asian Pacific Journal of Cancer Prevention. 2008; 9(1):7-14

59. Dias SJ, Li K, Rimando AM, Dhar S, Mizuno CS, Penman AD et al. Trimethoxy-Resveratrol and PiceatannolAdministeredOrally Suppress and Inhibit Tumor Formation andGrowth in Prostate CancerXenografts. The Prostate. 2013; 73:1135-1146. doi: 10.1002/pros.22657

60. Hsieh T and Wu JM. Differential effects on Growth, Cell Cycle Arrest, and induction of apoptosis by resveratrol in human prostate cancer cell lines. Experimental Cell Research. 1999; 249 (1): 109-115. doi: $10.1006 /$ excr.1999.4471

61. Wang TTY, Hudson TS, Wang TC, Remsberg CM, Davies NM, Takahashi $Y$ et al. Differential effects of resveratrol on androgen-responsive LNCaP human prostate cancer cells in vitro and in vivo. Carcinogenesis. 2008; .29 (10): 2001-2010. doi:10.1093/carcin/bgn131

62. Sheth S, Jajoo S, Kaur T, Mukherjea D, Sheehan K, Rybak LP et al. Resveratrol Reduces Prostate Cancer Growth and Metastasis by Inhibiting the Akt/MicroRNA-21 Pathway (Resveratrol and MicroRNA-21). Plos One 2012; 7(12): p.e51655. doi:10.1371/journal.pone.0051655

63. Brawley OW. Prostate cancer screening: Clinical applications and challenges. Urologic Oncology: Seminars and Original Investigations. 2004; 22(4): 353-357. doi:10.1016/j.urolonc.2004.04.014

64. Stacewicz-Sapuntzakis M and Bowen PE. Role of lycopene and tomato products in prostate health. Biochimica et Biophysica Acta-Molecular Basis of Disease. 2005; 1740 (2): 202- 205. doi:10.1016/j.bbadis.2005.02.004

65. Wan L, Tan HL, Thomas-Ahner JM, Pearl DK, Erdman JW, Moran NE et al. Dietary tomato and lycopene impact androgen signaling- and carcinogenesis-related gene expression during early TRAMP prostate carcinogenesis. Cancer prevention research. 2014; 7(12): 1228-1239. doi:10.1158/1940-6207.CAPR-14-0182

66. Gupta S, Afaq F, Mukhtar H. Selective Growth-Inhibitory, Cell-Cycle Deregulatory and Apoptotic Response of Apigenin in Normal versus Human Prostate Carcinoma Cells. Biochemical and 
Biophysical Research Communications. 2001; 287(4), 914-920. doi:10.1006/bbrc.2001.5672

67. Shukla S, Bhaskaran N, Babcook M, Fu P, Maclennan GT, Gupta S. Apigenin inhibits prostate cancer progression in TRAMP mice via targeting PI3K/Akt/FoxO pathway. Carcinogenesis, 2014; 35(2): 452460. doi:10.1093/carcin/bgt316

68. Ganai, SA. Plant-derived flavone Apigenin: The small-molecule with promising activity against therapeutically resistant prostate cancer. Biomedicine \& pharmacotherapy = Biomedecine \& pharmacotherapie. 2017; 85: 47-56. doi: 10.1016/j.biopha.2016.11.130

\section{Figures}
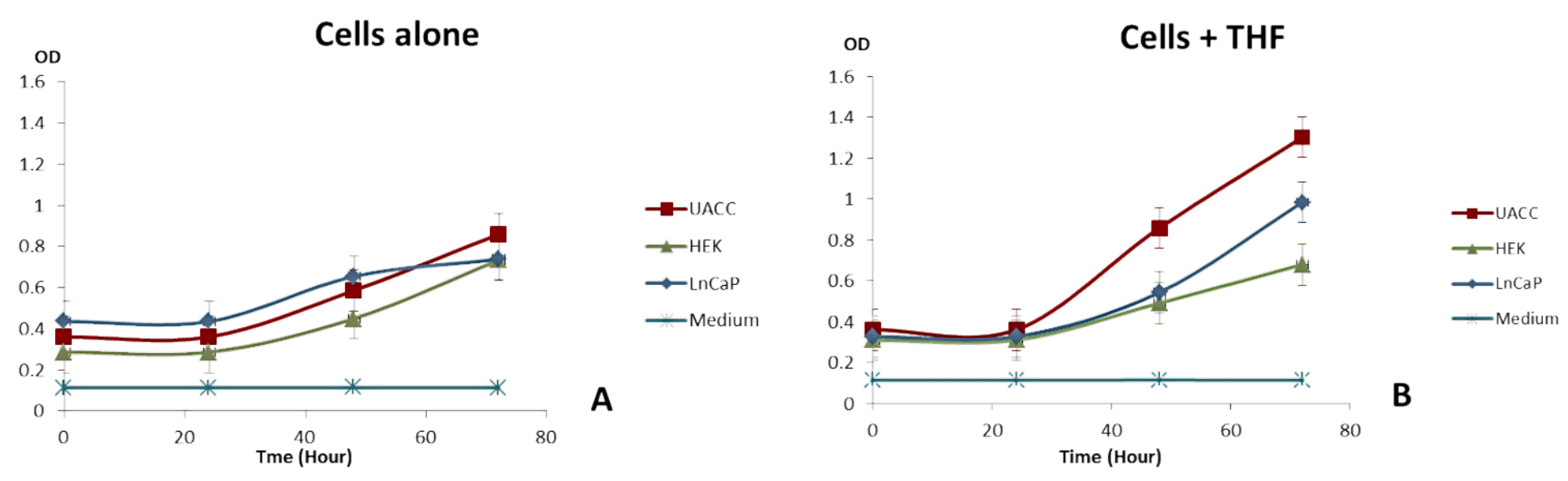

Figure 1

Viability of untreated cell lines. (A) Untreated cells alone. (B) Untreated cells plus THF, after incubation for 24,48 and 72 hours. 

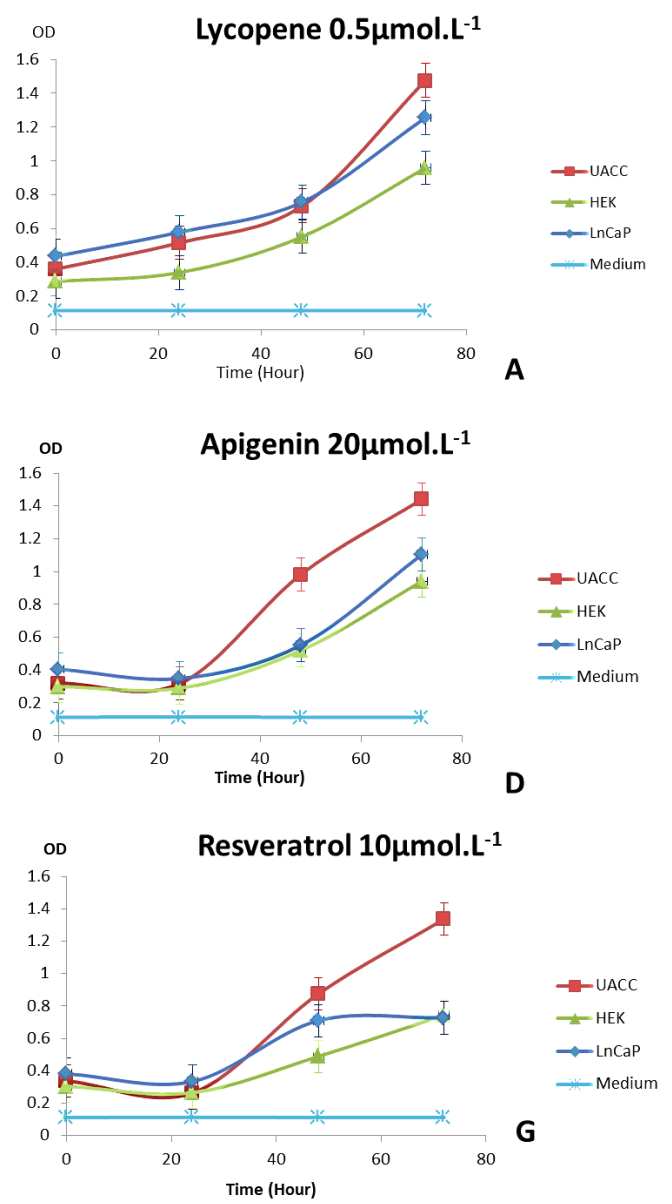
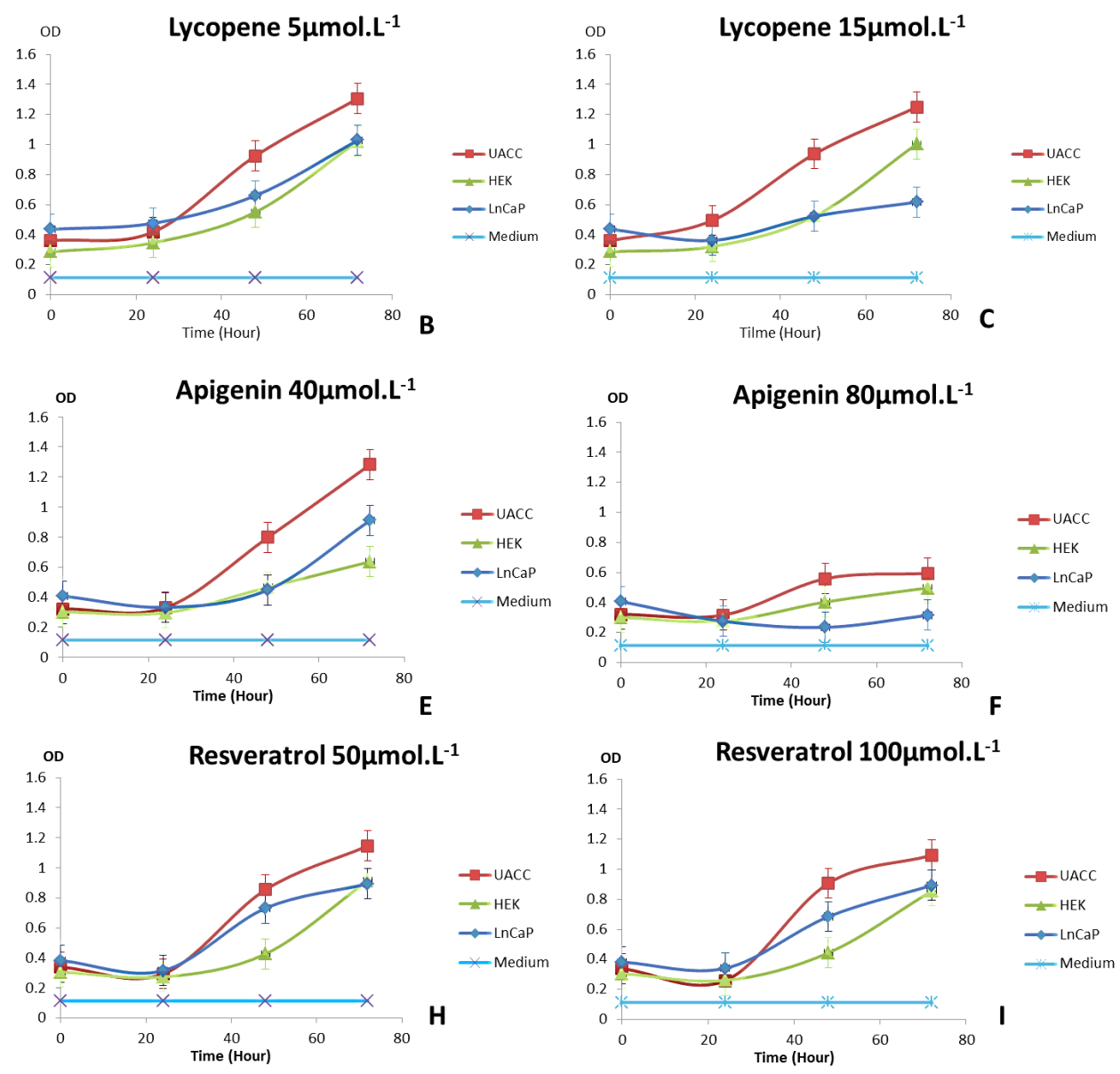

Figure 2

Viability of treated cell lines. Viability of cell lines treated with Lycopene (A, B, C), Apigenin (D, E, F) and Resveratrol $(\mathrm{G}, \mathrm{H}, \mathrm{I})$, after incubation for 24,48 and 72 hours.
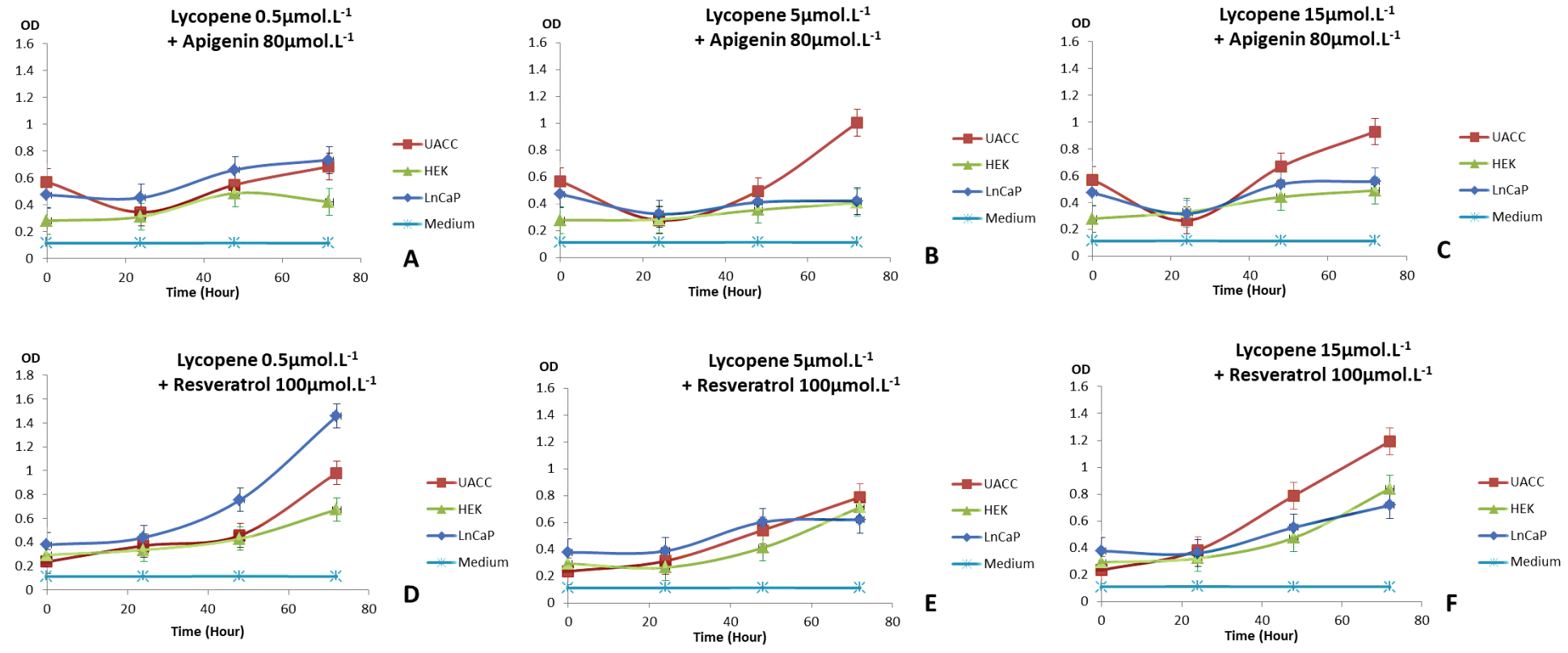

Figure 3 
Viability of cell lines treated with a combination of micronutrients. Cell lines treated with lycopeneapigenin (A, B and C) and with lycopene-resveratrol (D, E and F) after 24, 48 and 72 hours of incubation.

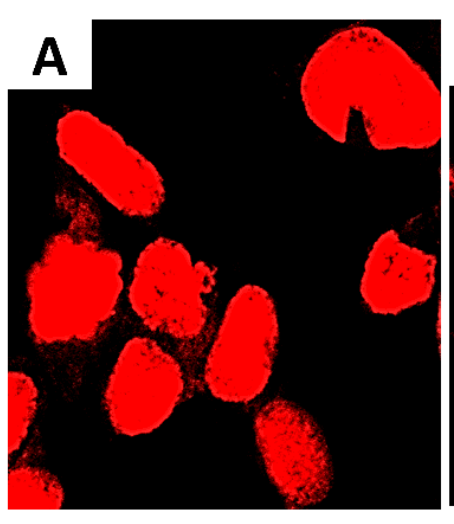

HEK anti-PCNA CONTROL

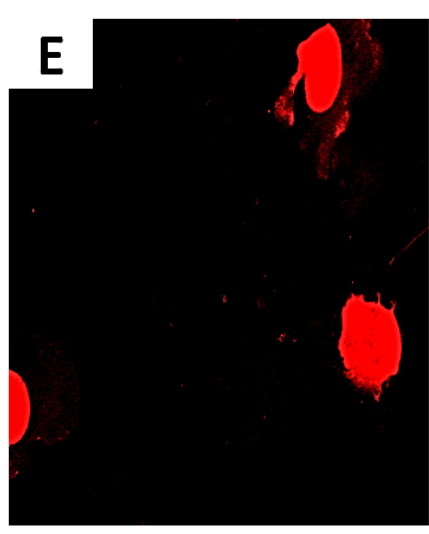

LNCaP anti-PCNA CONTROL

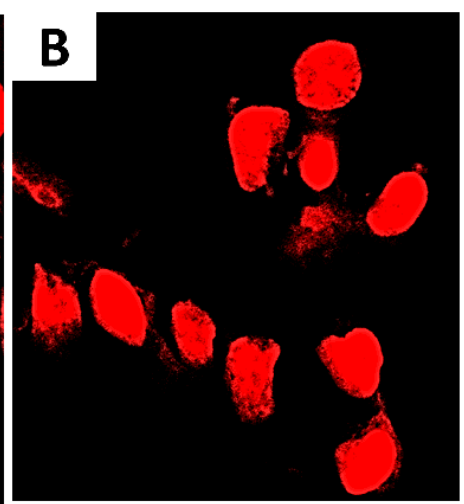

HEK anti-PCNA LYCOPENE $0.5 \mu \mathrm{mol} . \mathrm{L}^{-1}$

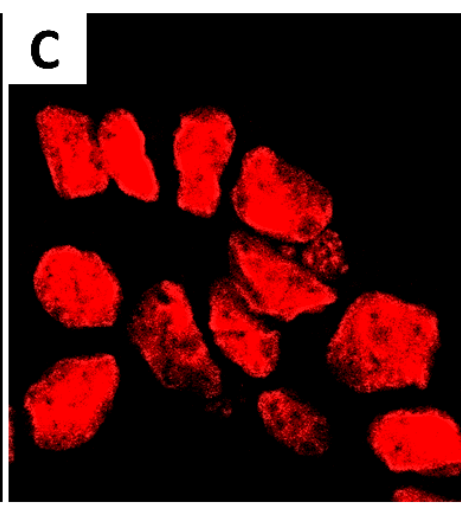

HEK anti-PCNA LYCOPENE $5 \mu$ mol.L $L^{-1}$

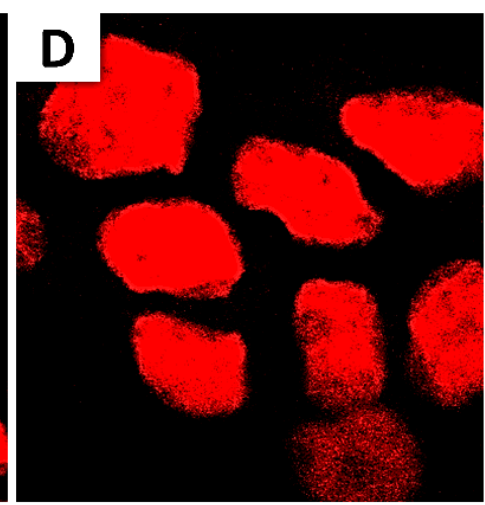

HEK anti-PCNA LYCOPENE $15 \mu$ mol.L-

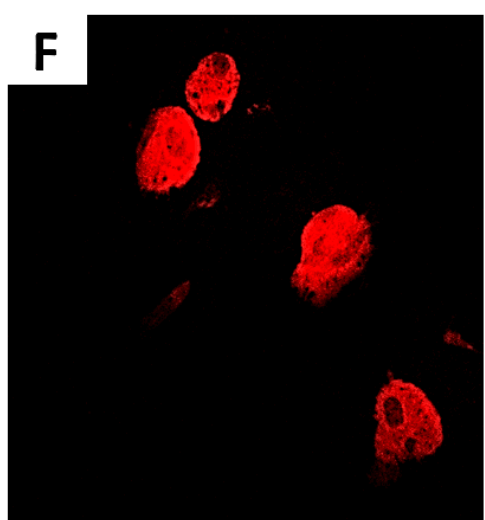

LNCaP anti-PCNA LYCOPENE $0.5 \mu$ mol. $\mathrm{L}^{-1}$

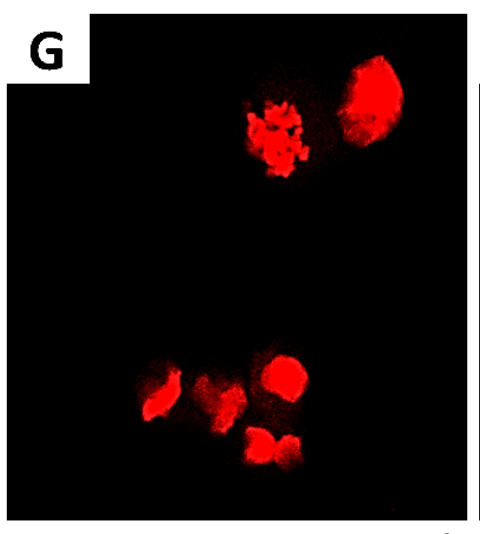

LNCaP anti-PCNA LYCOPENE $5 \mu \mathrm{mol} . \mathrm{L}^{-1}$

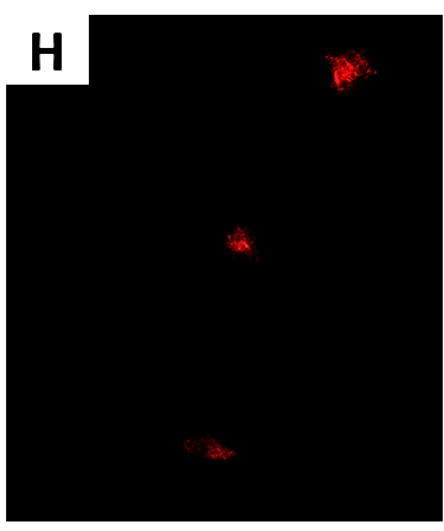

LNCaP anti-PCNA LYCOPENE $15 \mu \mathrm{mol} . \mathrm{L}^{-}$

\section{Figure 4}

Confocal evaluation of cell proliferation using anti-PCNA antibody. Evaluation of cell proliferation using anti-PCNA antibody on HEK cells not treated with lycopene (A) and treated with lycopene at a

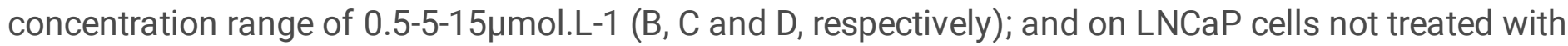
lycopene $(E)$ and treated with lycopene at a concentration range of $0.5-5-15 \mu \mathrm{mol} . \mathrm{L}-1(\mathrm{~F}, \mathrm{G}$ and $\mathrm{H}$, respectively) after 72 hours of incubation. 


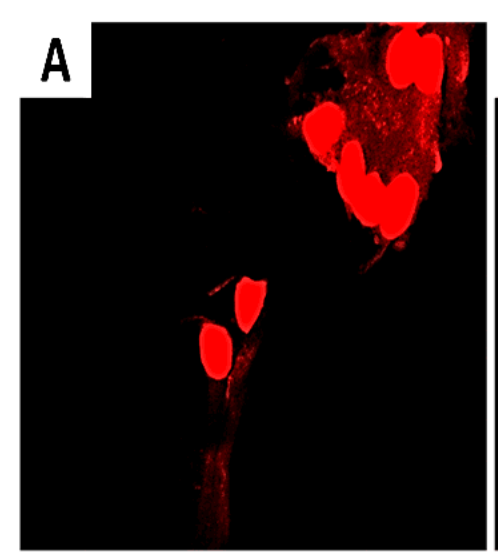

LNCAP anti-a-REDUCT CONTROL

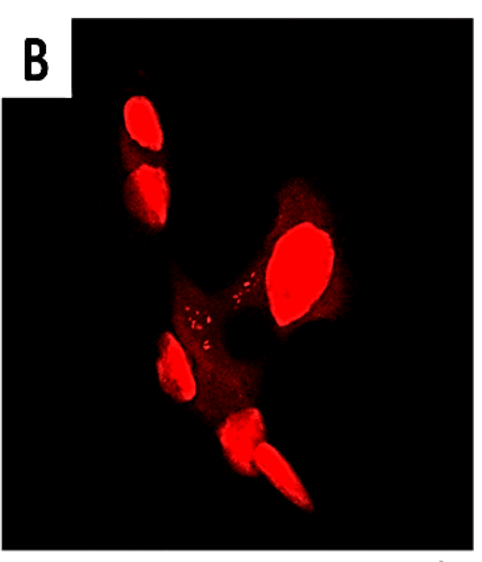

LNCaP anti- $a$-REDUCT LYCOPENE $15 \mu \mathrm{mol} . \mathrm{L}$

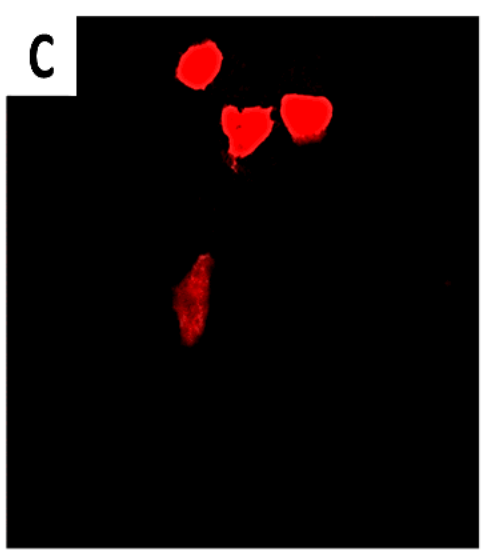

LNCaP $\alpha$-REDUCT APIGENTY $80 \mu$ mol.L ${ }^{-1}$

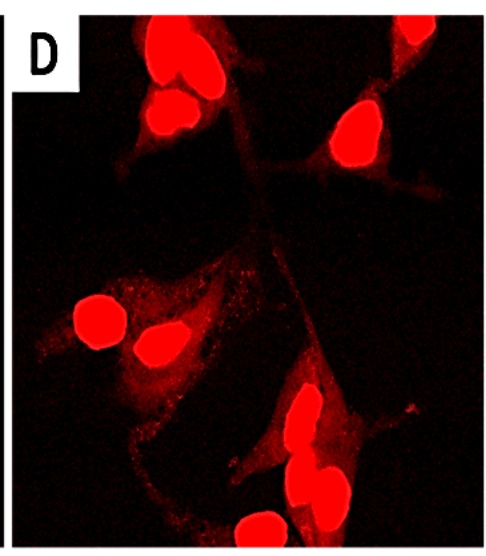

LNCaP anti- a-REDUCT RESVERATROL $100 \mu$ mol. ${ }^{-1}$

A

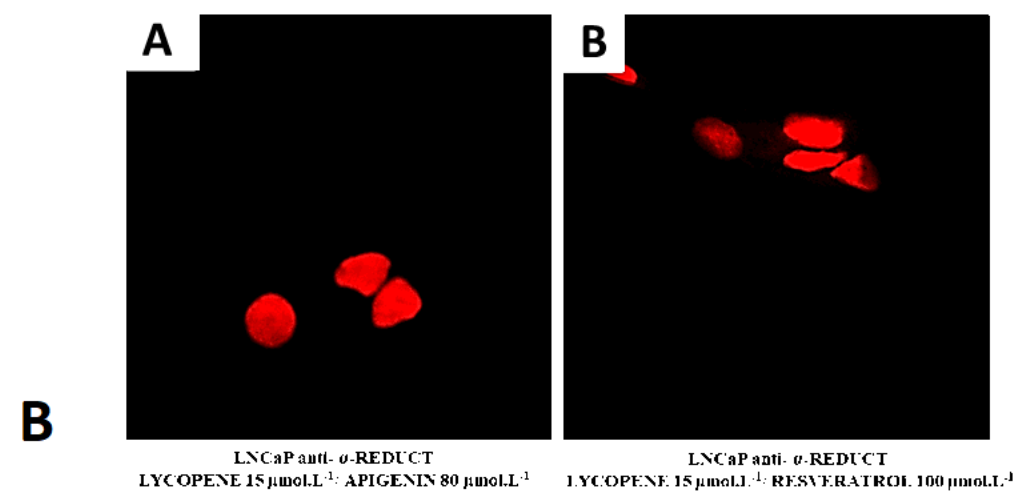

Figure 5

a. Confocal evaluation of anti-androgenic action, using anti-a-reductase, of lycopene, apigenin and resveratrol on LNCaP cells. Untreated LNCaP (A), LNCaP incubated with lycopene 15 $\mu$ mol.L-1 (B), LNCaP incubated with apigenin $80 \mu \mathrm{mol} . \mathrm{L}-1$ (C), and LNCaP incubated with resveratrol $100 \mu \mathrm{mol} . \mathrm{L}-1$ (D) after incubation for 72 hours. b. Confocal evaluation of anti-androgenic effects, using anti-a-reductase, of lycopene-apigenin and lycopene-resveratrol combinations on LNCaP cells. LNCaP incubated with the lycopene/apigenin $80 \mu \mathrm{mol} . \mathrm{L}-1$ combination (A), and LNCaP incubated with the lycopene $15 \mu \mathrm{mol} . \mathrm{L}-$ 1/resveratrol $100 \mu$ mol.L-1 combination (B) after incubation for 72 hours. 